\title{
GHRHIHaeIII Gene Polymorphism in Dairy and Beef Cattle at National Livestock Breeding Centers
}

\author{
A. O. Rini ${ }^{\mathrm{a}, *}$, C. Sumantri ${ }^{a}$, \& A. Anggraeni ${ }^{\mathrm{b}}$ \\ ${ }^{a}$ Department of Animal Production and Technology, Faculty of Animal Science, Bogor Agricultural University \\ Jln. Agatis, Kampus IPB Darmaga, Bogor 16680, Indonesia \\ 'Indonesian Research Institute for Animal Production \\ Jln. Veteran III, Desa Banjarwaru, Ciawi - Bogor 16002, Indonesia \\ (Received 26-07-2013; Reviewed 09-10-2013; Accepted 02-12-2013)
}

\begin{abstract}
This study was aimed to identify polymorphism of growth hormone releasing hormone (GHRH) gene in 89 heads of Holstein-Friesian (HF) dairy cattle from Lembang Artificial Insemination Center/ LAIC (17 bulls), Singosari Artificial Insemination Center/SAIC (32 bulls), and Cipelang Livestock Embryo Center/CLEC (40 cows); as well as in 4 breeds of female beef cattle from CLEC for comparison, providing Simmental (13 cows), Limousin (14 cows), Brahman (5 cows), and Angus (5 cows). This study used PCR-RFLP method by using HaeIII restriction enzyme. The enzyme cut the GHRH gene at nucleotides of GGICC at the base positions of 118, 312, and 406 and produced 4 fragments of 118, 194,94 , and $45 \mathrm{bp}$ respectively. Genotyping the GHRH gene produced two types of allele, namely A $(312,94$, and $45 \mathrm{bp})$ and $B(194,118,94$, and $45 \mathrm{bp})$. These two alleles resulted in three types of genotype, namely AA $(312,94$, and $45 \mathrm{bp}), \mathrm{AB}(312,194,118,94$, and $45 \mathrm{bp})$, and $\mathrm{BB}(194,118,94$, and $45 \mathrm{bp}$ ). Frequency of the B allele was dominant to the A allele. Chi-Square analysis showed that all of HF dairy and beef cattle observed were in Hardy-Weinberg equilibrium $\left(\mathrm{X}^{2}<\mathrm{X}_{(0.05)}^{2}\right)$. The highest heterozygosity value was $\mathbf{0 . 4 7 1}$ for HF bulls in LAIC, while the lowest one was for HF bulls in SAIC. Heterozygosity values in Simmental and Limousin cattles were higher than that of in HF cattle. The GHRH gene in HF and beef cattle was polymorphic, the exception was for Brahman with the only B allele. This result will improve the understanding of the polymorphism of GHRH gene in dairy and beef cattle.
\end{abstract}

Key words: beef cattle, genetic polymorphism, GHRHIHaeIII, Holstein Friesian, PCR-RFLP

\section{ABSTRAK}

Penelitian ini bertujuan untuk mengidentifikasi keragaman gen GHRH pada 89 ekor sapi Friesian Holstein di BIB Lembang (17 pejantan), BBIB Singosari (32 pejantan), dan BET Cipelang (40 betina); serta empat bangsa sapi pedaging betina dari BET Cipelang sebagai pembanding, meliputi Simental (13 ekor), Limousin (14 ekor), Brahman (5 ekor), dan Angus (5 ekor). Penelitian ini menggunakan metode PCR-RFLP dengan enzim restriksi HaeIII. Enzim HaeIII memotong sekuen gen GHRH pada nukleotida GGICC di posisi basa 118, 312, dan $406 \mathrm{pb}$, sehingga menghasilkan 4 fragmen dengan panjang 118, 194, 94, dan 45 pb. Genotyping gen GHRH menghasilkan 2 tipe alel, yaitu alel A $(312,94$, dan $45 \mathrm{pb})$ dan alel B $(194,118,94$, dan $45 \mathrm{pb})$. Kedua alel tersebut menghasilkan 3 genotipe, yaitu genotipe AA $(312,94$, dan 45 pb), AB $(312,194,118,94$, dan 45 pb), dan BB $(194,118$, 94, dan $45 \mathrm{pb}$ ). Frekuensi alel B lebih tinggi daripada alel A. Frekuensi alel A dan B di BIB Lembang adalah 0,235 dan 0,765, BBIB Singosari 0,234 dan 0,766, dan BET Cipelang 0,225 dan 0,775. Analisis Chi-Kuadrat menunjukkan bahwa sapi perah FH dan sapi pedaging pengamatan dalam keseimbangan Hardy-Weinberg $\left(\mathrm{X}^{2}<\mathrm{X}^{2}{ }_{(0,05)}\right)$, kecuali pada sapi FH di BIB Lembang, sapi Brahman, dan Angus di BET Cipelang. Nilai heterozigositas tertinggi adalah 0,471 untuk sapi FH pejantan di BIB Lembang, sebaliknya, nilai terendah adalah 0,344 untuk sapi FH pejantan di BBIB Singosari. Nilai heterozigositas sapi FH lebih rendah daripada sapi Simmental dan Limousin. Gen GHRH pada sapi FH dan sapi pedaging menunjukkan polimorfik, kecuali pada sapi Brahman yang hanya memiliki alel B.

Kata kunci: Friesian Holstein, gen GHRHIHaeIII, keragaman genetik, PCR-RFLP, sapi pedaging

*Corresponding author:

E-mail: annisa.oktavia@gmail.com 


\section{INTRODUCTION}

Indonesian dairy cattle population are currently around 597 heads (DGLAH, 2011). The current national dairy cattle milking problem is that a lower milk production compared to that of total milk demand. The capacity of milk production of domestic dairy cattle therefore should be increased, as the milking ability of HF dairy cows has just met around $35 \%$ of the national demand. One attempt that can be done to increase domestic milk production is by increasing both population and productivity of national HF dairy cattle.

To improve productivity of dairy cows can be done by several ways including the improvements on feeding, management, and genetic factors. Increasing genetic improvement of animals through conventional selection is commonly performed by evaluating their performance, but this method requires a long term process. Nowadays selection program has come to molecular approach that can give fast and efficient results. Progress in molecular technology allows selection to be done at molecular (DNA) level. A wide genetic polymorphism at DNA level has been identified, which can be used in the application of molecular selection program. The use of DNA marker in the selection program is often called as marker assisted selection (MAS) that is expected to increase selection response much better than that of without the use of DNA marker. DNA markers can be identified through nucleotide mutation in certain segments of genes to give an effective selection. Molecular selection has been focused on the genes relating to important traits, such as milk yield and milk fat production in dairy cattle, as well as growth and carcass weight in beef cattle (Achtung et al., 2001).

Growth hormone releasing hormone (GHRH) affects growth, development, and various metabolic regulation activities (Frajman et al., 2008); increases productivity in dairy cattle, such as increased milk production and milk fat (Shingu et al., 2004); as well as increases productivity in beef cattle, such as average daily gain, fat thickness and meat content of carcass (Pierzchala et al., 2003; Franco et al., 2005). On the other occasion, GHRH treatment might induce insulin resistance in lactating Japanese Black cows (Shingu et al., 2008).

The GH gene pathway contains various interdependent genes, such as IGF1 (insulin-like growth factor-1), PIT1 (pituitary-specific transcription factor-1), GHRH, and others. These genes are potential to be used as candidate markers because of their important physiological effects associated with economic traits (Franco et al., 2005; Biziene et al., 2011). The GH gene has been used as a genetic marker for growth traits in some species, providing also cattle (Jakaria et al., 2007). The GHRH gene product is released by the hypothalamus and acts on the adenophosphyse to stimulate secretion of growth hormone (Anderson et al., 2004; Rejduch, 2008). GHRH, also known as growth-hormone-releasing factor (GRF or GHRF) or somatocrinin, is a 44-amino acid peptide hormone produced in the secretory neuron of the hypotalamus (Hartman, 2000). The polymorphism of GHRH gene has been reported in some species such as cattle (Kmiec et al., 2007; Dybus \& Greziak, 2003; Piatkowska et al., 2011; Sumantri et al., 2011), pig (Cho et al., 2009; Pierzchala et al., 2003; Franco et al., 2005), and buffalo (Sumantri et al., 2010).

Two National Artificial Insemination Centers (LAIC and SAIC), and CLEC are expected to produce superior livestock breeding stock. LAIC and SAIC have main functions to provide replacement of superior bulls and superior sperm continuously by producing and distributing frozen semen, while CLEC has main functions for production, storage and distribution of cattle embryos as well as embryo transfer applications.

In regarding to produce livestocks with high productivity requires the genetic improvement by consistent selection. Genetic improvement has been made in the basic knowledge of animal genetic characteristics that affect the traits considered. The GHRH gene is a major gene that can be considered as a potential gene (marker) in the selection for giving genetic improvement of both growth and milk production traits in dairy cattle. Particular attention should be paid to the cattle of having homozygous GHRH AA genotype, which were found to be characterized by the highest values for the following traits: milk yield $(\mathrm{kg})$, fat yield $(\mathrm{kg})$, protein yield $(\mathrm{kg})$ as well as total fat and protein yield $(\mathrm{kg})$ and fat protein content (\%) (Kmiec et al., 2007; Dybus \& Greziak, 2006).

This research therefore was aimed to identify the GHRHIHaeIII gene polymorphism in HF dairy cattle and beef cattle at National Livestock Breeding Centers as an initial information for making genetic improvement of meat and milk production through molecular selection.

\section{MATERIALS AND METHODS}

\section{Sample Sources}

Blood samples used totally were 126 cattles, that were collected from $49 \mathrm{HF}$ bulls from LAIC (17 heads), SAIC (32 heads), and HF cows from CLEC (40 heads); as well as a number of 37 heads of 4 breeds of female beef cattle, consisting of Simmental (13 cows), Limousin (14 cows), Brahman (5 cows), and Angus (5 cows) from CLEC. Blood samples were already extracted as DNA collections at the Laboratory of Livestock Molecular Genetic, Livestock Breeding and Genetic, Faculty of Animal Science, Bogor Agricultural University.

\section{DNA Extraction}

Blood samples were collected from each cattle in $10 \mathrm{~mL}$ non anticoagulant polypropylene tubes. Blood samples then were mixed with $96 \%$ ethanol. The process of DNA isolation used phenol-chloroform method (Sambrook et al., 1989) then were dissolved in TE buffer. Genomic DNA was stores at $-20{ }^{\circ} \mathrm{C}$ until amplification with polymerase chain reaction (PCR).

\section{Polymerase Chain Reaction (PCR)}

Amplification of Polymerase Chain Reaction (PCR) was carried out using specific primer (Moody et al.,1995) which previously being modified, for parts of exon 2, intron 2, and most of exon 3. Primers used were for 
forward 5'-TGA AGG ATG CTG CTC TGG GT-3 'and reverse 5'TGC ATG ATA TTC CTG TCC TGG A-3' (Gen Bank access number AF242855). The PCR was performed in a final volume of $15 \mu \mathrm{L}$ for each reaction containing $1 \mu \mathrm{L}$ of DNA sample, $9.7 \mu \mathrm{L}$ water destillated, $0.1 \mu \mathrm{L}$ primers, $0.05 \mu \mathrm{L}$ Taq polymerase, buffer $1.25 \mu \mathrm{L}, 0.1$ $\mu \mathrm{L}$ dNTPs, and $0.25 \mu \mathrm{L} \mathrm{MgCl}_{2}$. The reaction mixture was subjected to an initial $5 \mathrm{~min}$ of denaturation $94{ }^{\circ} \mathrm{C}$, followed by 35 cycles of denaturation $94{ }^{\circ} \mathrm{C}$ for $45 \mathrm{sec}$, annealing $45 \mathrm{sec}$ at $62{ }^{\circ} \mathrm{C}$, extension $1 \mathrm{~min}$ at $72{ }^{\circ} \mathrm{C}$, and a final extension $5 \mathrm{~min}$ at $72{ }^{\circ} \mathrm{C}$.

\section{PCR-RFLP Analysis}

Visualization of amplification was analyzed on agarose gel 1,5\% containing $2.5 \mu \mathrm{L}$ EtBr (ethidium bromide), 0.5X TBE buffer (1 M Tris, 0.9 M Boric acid, 0.01 M EDTA pH 8.0) with a $100 \mathrm{bp}$ ladder as a molecular weight marker for confirmation of the length of PCR product. For digestion by using enzyme and determination of RFLP, $5 \mu \mathrm{L}$ of PCR products was added to 0,3 $\mu \mathrm{LHaeIII}$ enzyme, $1 \mu \mathrm{L}$ destilated water, and $0.7 \mu \mathrm{L} R$ buffer. The mixture was then incubated at $37{ }^{\circ} \mathrm{C}$ for 16 hour. The digestion products were separated by horizontal electrophoresis (100 volts, $40 \mathrm{~min}$ ) in $2 \%$ agarose gel in $0.5 \mathrm{X}$ TBE and $2.5 \mu \mathrm{L}$ ethidium bromide visualized on UV transiluminator.

\section{Data Analysis}

Genotype and allele frequencies. PCR-RFLP data were analyzed by calculating allele and genotype frequencies (Nei \& Kumar, 2000). Genotype frequency, determined by the calculation of the ratio of a specific genotype in each population, was calculated by the following formula:

$$
x_{i i}=n_{i i} / N
$$

Allele frequency was calculated as ratio of a certain allele to the overall alleles at a certain locus in a population. Allele frequency of GHRH gene I HaeIII was calculated by the following formula:

$$
x_{i}=\left(2 n_{i i}+\sum n_{i j}\right) / 2 N
$$

Description:

$x_{i i}=$ Frequency of genotype $\mathrm{AiAi}$

$x_{i}=$ Frequency of allel Ai

$\mathrm{n}_{\mathrm{i}}=$ Number of genotype AiAi

$n_{i j}=$ Number of genotype AiAj

$\mathrm{N}=$ Total samples

Hardy-Weinberg equilibrium (HW). Hardy-Weinberg equilibrium was tested by the $\chi^{2}$ (Chi-Square) (Nei \& Kumar, 2000):

$$
x^{2}=\sum(\mathrm{O}-\mathrm{E})^{2} / \mathrm{E}
$$

Description:

$\chi^{2}=$ Hardy Weinberg equilibrium test

$\mathrm{O}=$ Observed number of genotype A11

$\mathrm{E}=$ Expected number of genotype A11
Degree of freedom (df) was according to Allendorf \& Luikart (2007):

$\mathrm{df}=($ Number of genotype $-\mathrm{i})-($ Number of allele $-\mathrm{j})$

Heterozygosity. Heterozigosity was tested (Weir, 1996) by the following formula:

$$
\mathrm{Ho}=\sum_{\mathrm{i} \neq \mathrm{j}} \mathrm{n}_{\mathrm{ij}} / \mathrm{N}
$$

Ho $=$ Heterozosity observation

$\mathrm{n}_{\mathrm{ij}}=$ Number of heterozygous animal

$\mathrm{N}=$ Number of observed animal

Heterozygosity expectation ( $\mathrm{He}$ ) based on allele frequencies (Nei \& Kumar, 2000) was calculated by the following formula:

$$
\mathrm{He}=1-\sum_{\mathrm{i}=1}^{\mathrm{q}} x_{i}^{2}
$$

Description:

$\mathrm{He}=$ Heterozigosity expectation

$x_{i}=$ Frequency of allele

$\mathrm{q}=$ Total alleles

Fixation index. Fixation index in each source was obtained from equation:

$$
\mathrm{F}_{\text {ISki }}=\left(\mathrm{X}_{\mathrm{kii}}-\mathrm{X}_{\mathrm{ki}}^{2}\right) /\left[\mathrm{X}_{\mathrm{ki}}\left(1-\mathrm{X}_{\mathrm{ki}}\right)\right.
$$

Description:

$\mathrm{X}_{\mathrm{kii}}=$ Frequency of homozygot genotype $i$ in $k$ population $\mathrm{X}_{\mathrm{ki}}=$ Frequency of allele $i$

\section{RESULTS AND DISCUSSION}

\section{GHRH Gene Amplification}

Amplification of the GHRH gene resulted an amplicon with the length of $451 \mathrm{bp}$, which is located in partial exon 2, intron 2, and partial exon 3. Moody et al. (1995) who conducted a study using Hereford and Angus cows, discovered the diversity of the GHRH gene in intron 2. The amplification fragment of the GHRH gene was performed in the thermocycler machine with an annealing temperature of $62{ }^{\circ} \mathrm{C}$. The amplification of the GHRH gene fragment was carried on GeneAmp ${ }^{\circledR}$ PCR System 9700 (Applied Biosystem). The success rate of the GHRH gene amplification in this study was 100\%. Gene segment amplification products were visualized on $1.5 \%$ agarose gel as shown in Figure 1. Position of annealing primers of the GHRH gene sequences was shown in Figure 2.

\section{GHRH|HaeIII Gene Polymorphism}

Genetic polymorphism of the GHRH gene was done by PCR-RFLP method using HaeIII restriction enzyme. This enzyme recognized and cut at nucleotides of GGICC sites. Based on the amplification results of the GHRH gene sequence, it was found three cut points of the HaeIII restriction enzyme, namely at 4472, 4666, and 4760 nucleotides or at the base positions of 118,312 , and $406 \mathrm{bp}$ of the PCR products. RFLP process resulted in four fragments with the base lengths of 118, 194, 94, and $45 \mathrm{bp}$. These fourth bands showed as a B allele. If there 
$\begin{array}{lllllllllllllll}M & 1 & 2 & 3 & 4 & 5 & 6 & 7 & 8 & 9 & 10 & 11 & 12 & 13 & 14\end{array}$

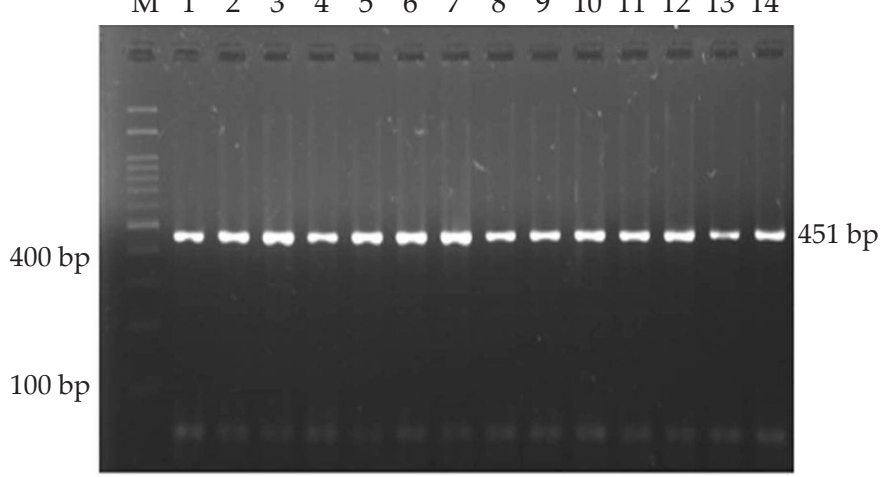

Figure 1. Growth hormone releasing hormone gene amplification results in $1.5 \%$ agarose gel. $\mathrm{M}=$ Marker; No. 1-14= Number of sample.

was a base change at position 4474, from the base $\mathrm{C}$ (Citosin) changing to A (Adenine), it caused HaeIII cutting the fragments (bands) resulting an A allele. Figure 3 showed that the diversity found in intron 2 region of the GHRH gene. Intron is an internal space between protein-coding bases and will disappear during the process of transcription or splicing (Kim et al., 2007).

Results from the PCR-RFLP analysis of the GHRHIHaeIII gene segments were polymorphic. There were three genotypes identified, namely $\mathrm{AA}, \mathrm{AB}$, and $\mathrm{BB}$ genotypes that were derived from two alleles, namely $A$ and B alleles. Nei \& Kumar (2000) stated that an allele was polymorphic if frequency of that allele was equal or less than 0.99 .

Three variant genotypes were found in HF bulls and cows as well as in four breeds of female beef cattle from this study, these were $\mathrm{AA}, \mathrm{BB}$, and $\mathrm{AB}$ genotypes (Figure 3). Genotyping the GHRHIHaeIII gene, showed for the resulted three fragments of 312, 94, and $45 \mathrm{bp}$, identified for the AA genotype; four fragments of 194, 118,94 , and $45 \mathrm{bp}$ for the BB genotype; and five fragments of $312,194,118,94$, and $45 \mathrm{bp}$ for the AB geno-

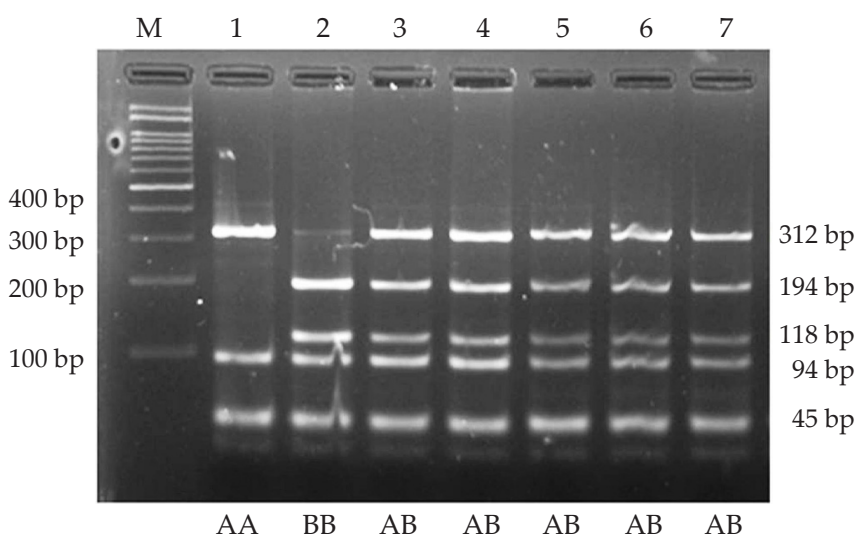

Figure 3. Growth hormone releasing hormone gene fragment using PCR-RFLP method with HaeIII restriction enzyme on $2 \%$ agarose gel. $M=$ Marker; $1-7=$ Number of samples; $\mathrm{AA}, \mathrm{AB}, \mathrm{BB}=$ Genotype.

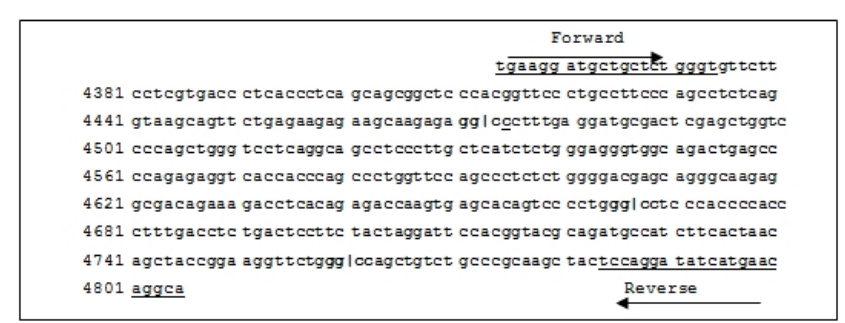

A Allele 5'-GCAAGAGAGGCACTTTGA-3'

B Allele $\quad 5^{\prime}$-GCAAGAGAGGCCTTTGA-3'

Figure 2. Primer position, PCR product and the difference in growth hormone releasing hormone gene sequences (GenBank access number AF242855) and HaeIII restriction enzyme. The bottom line shows the primer; bold text shows the restriction site; bold underlined shows the mutation site; $\mathrm{A}$ allele has $\mathrm{A}$ base sequence at position 4474; B allele has $\mathrm{C}$ base sequence at position 4474 .

type. Identification of the GHRH gene polymorphism in cattle has been done by PCR-RFLP using HaeIII restriction enzyme by Moody et al. (1995) who reported the presence of two types of alleles, namely A and $\mathrm{B}$ alleles with three kinds of genotypes, namely $\mathrm{AA}, \mathrm{AB}$ and $\mathrm{BB}$ genotypes. The diversity of GHRHIHaeIII gene in HF cattles and beef cattles (Simmental, Limousin, Brahman, and Angus) were indicated by the number of genotypes that appeared from each breed (Figure 4).

\section{Genotype and Allele Frequencies of the GHRH Gene}

Results of the GHRH।HaeIII gene analysis showed that the frequency of the BB genotype (0.584) in dairy cows in LAIC, SAIC, and CLEC was higher compared with the $\mathrm{AB}$ genotype frequency (0.371) and the AA genotype frequencies (0.045). For beef cattle at CLEC showed that freuency of the $\mathrm{AB}$ genotype (0.486) was

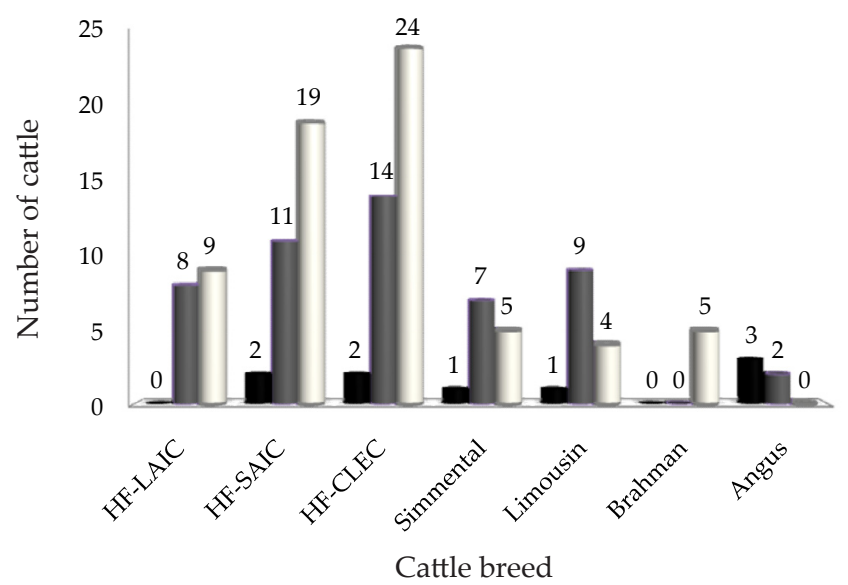

Figure 4. The diversity of GHRH $\mid$ HaeIII gene $(\boldsymbol{m}=\mathrm{AA} ; \varpi=\mathrm{AB}$; $\square=\mathrm{BB})$ in Holstein Friesian and Beef Cattle. HF cattle= Lembang AIC/LAIC ( $\hat{\sigma}^{\Uparrow}$, Singosari AIC/SAIC $(\hat{\jmath})$, and Cipelang LEC/CLEC ()); Cipelang LEC Beef Cattle $(+)=$ Simental, Limousin, Angus and Brahman . 
higher than those of the AA (0.135) and the BB (0.378) ones. Brahman beef cattle had the only $\mathrm{BB}$ genotype (1.000). Frequencies of the $\mathrm{AB}$ genotype in Simmental (0.538) and Limousin (0.643) were higher than those of the AA and the BB genotypes. For Angus cattle, frequency of the AA genotype (0.600) was higher those of the other genotypes. Genotype and allele frequencies of the GHRH gene of HF cattle and beef cattle are shown in Table 1.

Frequency of the B allele (0.770) for HF bulls in LAIC, SAIC, and HF cows in CLEC was higher than that of the A allele (0.230). Further, frequency of allele A and B of HF bulls in LAIC, SAIC, as well as HF cows in CLEC were succesively 0.235 and $0.765 ; 0.234$ and 0.766 , as well as 0.225 and 0.775 . For beef cattles in CLEC showed frequencies of both the A and B alleles were in Simmental for 0.346 and 0.654, Limousin 0.393 and 0.607, and Brahman 0.000 and 1.000. Brahman cattle were monomorphic as the only B allele was found. However, different occasion was found in Angus cattle, as the A allele had a higher ferquency (0.800) than the B allele (0,200). Moody et al. (1995) also found the same condition in Angus cattle for a high frequency for the A allele (0.700).

Previous study of genetic diversity of the $\mathrm{GH}$ gene I AluI in HF dairy cattle at the same these livestock breeding stations by Misrianti et al. (2012) reported that all HF cattle observed had only two genotypes, namely LL and LV genotypes, without VV genotype. Frequencies of the LL genotype reported very high compared to the LV genotype, were $0.84-0.95$ vs. 0.05 to 0.16 . Genotype frequencies of the GHR $\mid A l u I$ gene in

Table 1. Genotype and allele frequencies of the growth hormone releasing hormone $(\mathrm{GHRH})$ gene

\begin{tabular}{|c|c|c|c|c|c|c|}
\hline \multirow{2}{*}{$\begin{array}{c}\text { Breed } \\
\text { (heads) }^{*}\end{array}$} & \multirow{2}{*}{ Source } & \multicolumn{3}{|c|}{ Genotype } & \multicolumn{2}{|c|}{ Allele } \\
\hline & & AA & $\mathrm{AB}$ & BB & $\mathrm{A}$ & $\mathrm{B}$ \\
\hline \multicolumn{7}{|c|}{ Holstein Friesian } \\
\hline $\begin{array}{l}\mathrm{HF} \hat{~} \hat{} \\
(17)\end{array}$ & LAIC & $\begin{array}{l}0.000 \\
(0)\end{array}$ & $\begin{array}{l}0.471 \\
(8)\end{array}$ & $\begin{array}{l}0.529 \\
(9)\end{array}$ & 0.235 & 0.765 \\
\hline $\begin{array}{l}\mathrm{HF} \hat{0} \\
(32)\end{array}$ & SAIC & $\begin{array}{l}0.063 \\
(2)\end{array}$ & $\begin{array}{c}0.344 \\
(11)\end{array}$ & $\begin{array}{c}0.594 \\
(19)\end{array}$ & 0.234 & 0.766 \\
\hline $\begin{array}{l}\mathrm{HF}+ \\
(40)\end{array}$ & CLEC & $\begin{array}{l}0.05 \\
(2)\end{array}$ & $\begin{array}{l}0.35 \\
(14)\end{array}$ & $\begin{array}{c}0.600 \\
(24)\end{array}$ & 0.225 & 0.775 \\
\hline Sub total (89) & & $\begin{array}{l}0,045 \\
(4)\end{array}$ & $\begin{array}{c}0.371 \\
(33)\end{array}$ & $\begin{array}{l}0.584 \\
(52)\end{array}$ & 0.230 & 0.770 \\
\hline \multicolumn{7}{|l|}{ Beef cattle } \\
\hline $\begin{array}{l}\text { Simmental 우 } \\
\text { (13) }\end{array}$ & CLEC & $\begin{array}{l}0.077 \\
(1)\end{array}$ & $\begin{array}{l}0.538 \\
(7)\end{array}$ & $\begin{array}{l}0.385 \\
(5)\end{array}$ & 0.346 & 0.654 \\
\hline $\begin{array}{l}\text { Limousin } q \\
(14)\end{array}$ & CLEC & $\begin{array}{l}0.071 \\
(1)\end{array}$ & $\begin{array}{l}0.643 \\
(9)\end{array}$ & $\begin{array}{c}0.286 \\
(4)\end{array}$ & 0.393 & 0.607 \\
\hline $\begin{array}{l}\text { Brahman }+ \\
\text { (5) }\end{array}$ & CLEC & $\begin{array}{l}0.000 \\
(0)\end{array}$ & $\begin{array}{l}0.000 \\
(0)\end{array}$ & $\begin{array}{l}1.000 \\
(5)\end{array}$ & 0.000 & 1.000 \\
\hline $\begin{array}{l}\text { Angus }+ \\
\text { (5) }\end{array}$ & CLEC & $\begin{array}{l}0.600 \\
(3)\end{array}$ & $\begin{array}{l}0.400 \\
(2)\end{array}$ & $\begin{array}{l}0.000 \\
(0)\end{array}$ & 0.800 & 0.200 \\
\hline Sub total (37) & & $\begin{array}{l}0.135 \\
(5)\end{array}$ & $\begin{array}{c}0.486 \\
(18)\end{array}$ & $\begin{array}{c}0.378 \\
(14)\end{array}$ & 0.378 & 0.622 \\
\hline
\end{tabular}

Note: $(\ldots) *=$ Number of samples; $\hat{\partial}=$ Bulls; + $=$ Cows; LAIC $=$ Lembang Artificial Insemination Center; $\mathrm{SAIC}=$ Singosari Artificial Insemination Center; CLEC= Cipelang Livestock Embryo Center. native/local cattles and some commercial beef cattles as reported by Zulkharnaim et al. (2010) reported also three types of AA, AG, and GG genotypes. Genotype frequencies of Bali cattle were for AA (0.988), GG (0.006) and AG (0.006), stated that as a monomorphic evidence of this gene. Contrastly, genotype frequencies of this gene were mostly different for Limousin GG (0.667), AA (0.238) and AG (0.095), Simmental AG (0.529), GG (0.471) and AA (0.000), Pesisir AA (0.604), GG (0.375) and AG (0.021) stated as polymorphic evidences.

Dybus \& Grzesiak (2006) in their study on the evaluation of the diversity of GHRH gene with milk production in Poland dairy cattle. From that study identified three genotypes and two alleles, by the genotypes of AA (0.0545), AB (0.3133) and BB (0.6322); as well as by the alleles of A (0.2111) and B (0.7889). Cows having $\mathrm{AA}$ and $\mathrm{AB}$ genotypes were reported of producing more fat in their milk. In similar to the previous study, Szatkowska et al. (2009) reported for Jersey cattle that the AA cows produced a higher fat composition but a lower milk production compared to those of the $\mathrm{AB}$ or $\mathrm{BB}$ cows. The results indicatet that genetic polymorphism of a certain fragment of the GHRHIHaeIII gene could be used as MAS for selecting breeding cows for having high genetic ability in producing milk fat and other milk composition.

According to Cheong et al. (2006), the GHRH gene was such a genetic marker for meat production. They reported that there was a relationship between genotype diversity of GHRH gene with the percentage of carcass weight and muscular parts of longisimus in Korean native beef cattle (Hanwoo). The results showed that the GHRH gene diversity could be an important factor in affecting meat and carcass in beef cattle.

\section{Hardy-Weinberg Equilibrium}

Focussing in HF dairy cattle, results showed that HF bulls in SAIC and HF cows on CLEC were in HardyWeinberg equilibrium; while focussing in beef cattle showed that Simmental and Limousin were in HardyWeinberg equilibrium with Chi-squared value $\chi^{2}<\chi^{2}{ }_{(0.05)}$. The values of Hardy-Weinberg equilibrium analysis in the GHRH gene as tested by Chi-square $\left(\chi^{2}\right)$ are shown in Table 2.

Hardy-Weinberg law states that the frequency of genotypes in a large population should always be in balance when there were no selection, migration, mutation and genetic drift (Noor, 2008). However, the HardyWeinberg equilibrium in HF cows in LAIC, Brahman and Angus cattle in CLEC could not be calculated because they were not qualify of Hardy-Weinberg testing.

\section{Heterozygosity}

Heterozygosity value is the most accurate way to measure the genetic diversity of population (Nei \& Kumar, 2000). Heterozygosity values are influenced by number of samples, number of alleles and allele frequencies. Javanmard et al. (2005) suggested that heterozygosity values below $0.5(50 \%)$ as an indicator of a low variation of a gene in the population. The results 
Table 2. Hardy-Weinberg equilibrium of growth hormone releasing hormone $(\mathrm{GHRH})$ gene

\begin{tabular}{|c|c|c|}
\hline Breed (heads) ${ }^{*}$ & Source & $x^{2}$ \\
\hline \multicolumn{3}{|l|}{ Holstein Friesian } \\
\hline $\operatorname{HF} \precsim(17)$ & LAIC & nc \\
\hline $\mathrm{HF} \hat{\jmath}(32)$ & SAIC & $0.057^{\mathrm{ns}}$ \\
\hline $\mathrm{HF}+(40)$ & CLEC & $0.001^{\mathrm{ns}}$ \\
\hline Sub total & & $0.186^{\mathrm{ns}}$ \\
\hline \multicolumn{3}{|l|}{ Beef cattle } \\
\hline Simmental $q$ (13) & CLEC & $0.467^{\mathrm{ns}}$ \\
\hline Limousin 9 (14) & CLEC & $1.691^{\mathrm{ns}}$ \\
\hline Brahman $q(5)$ & CLEC & nc \\
\hline Angus ${ }_{+}(5)$ & CLEC & nc \\
\hline Sub total & & $0.044^{\text {tn }}$ \\
\hline
\end{tabular}

Note: $(\ldots)^{*}=$ Number of samples; ns $=$ not significant at level $\alpha=0.05$, nc= not calculable; $\chi 2(0,05)=3.84 ; \hat{\gamma}=$ Bulls; + $=$ Cows; LAIC= Lembang Artificial Insemination Center; SAIC $=$ Singosari Artificial Insemination Center; $\mathrm{CLEC}=$ Cipelang Livestock Embryo Center.

showed that heterozygosity values of HF cattle ranged from 0.344 to 0.471 (Table 3). The observed heterozygosity values were greater than the expected heterozygosity values for the exection in HF bulls in SAIC. The highest heterozygosity value of 0.471 was found in HF bulls in LAIC. The observation heterozygosity values in beef cattle ranged from 0.000 to 0.643 . The lowest heterozygosity in beef cattle was in Brahman cattle due to no any variation in its genotype (0.000), whilst the highest one was in Limousin cattle (0643). A high heterozygosity value showed the diversity of the GHRHIHaeIII gene in the population was high.

Based on the analysis, it was also showed that Ho and $\mathrm{He}$ values in HF bulls and HF cows were almost similar $(\mathrm{Ho}=0.371$ and $\mathrm{He}=0.355)$. This similar occasion

Table 3. Heterozygosity values (Ho) and expected $(\mathrm{He})$ of growth hormone releasing hormone (GHRH) gene

\begin{tabular}{|c|c|c|c|}
\hline Breed (heads)* & Source & Ho & $\mathrm{He}$ \\
\hline \multicolumn{4}{|l|}{ Holstein Friesian } \\
\hline $\mathrm{HF} \hat{\jmath}(17)$ & LAIC & 0.471 & 0.360 \\
\hline $\mathrm{HF} \hat{\jmath}(32)$ & SAIC & 0.344 & 0.359 \\
\hline $\mathrm{HF}+(40)$ & CLEC & 0.350 & 0.349 \\
\hline Sub total & & 0.371 & 0.355 \\
\hline \multicolumn{4}{|l|}{ Beef cattle } \\
\hline Simmental $q(13)$ & CLEC & 0.538 & 0.453 \\
\hline Limousin $+(14)$ & CLEC & 0.643 & 0.477 \\
\hline Brahman 우 (5) & CLEC & 0.000 & 0.000 \\
\hline Angus $\bigcirc$ (5) & CLEC & 0.400 & 0.320 \\
\hline Sub total & & 0.486 & 0.470 \\
\hline
\end{tabular}

Note: $(\ldots)^{*}=$ Number of samples; $\hat{\jmath}=$ Bulls; $q=$ Cows; LAIC= Lembang Artificial Insemination Center; $\mathrm{SAIC}=$ Singosari Artificial Insemination Center; CLEC $=$ Cipelang Livestock Embryo Center. was also found in beef cattle $(\mathrm{Ho}=0.486$ and $\mathrm{He}=0.470)$. However, a different occasion occurred in Limousin cattle that resulted a higher heterozygosity value $(\mathrm{Ho}=$ 0.477 and $\mathrm{He}=0.643$ ). Generally, the expectation for a high heterozygosity value is that as a genetic identifier in explaining level of genetic diversity in a population of domestic livestock (Moioli et al., 2004).

\section{Fixation Index}

Fixation index can be used to determine breeding pattern and selection in population. The value of fixation index could be positive or negative, it was influenced by selection, inbreeding, and assortative mating. The highest fixation index value was in SAIC HF cattle $\left(0.046^{\mathrm{A}}\right)$, whilst the lowest one was in CLEC $\left(-0.003^{\mathrm{A}}\right.$ and $\left.-0.003^{\mathrm{B}}\right)$ (Table 4). Fixation index values in this study were spreading. These indicated that there was no-occurrence of fixation of GHRH gene or no identifed one allele type, meaning for a random mating still occurring. Further, the GHRH gene was in fixation in Brahman beef cattle in CLEC due to a monomorfic occurence.

Table 4. Index fixation value of growth hormone releasing hormone (GHRH) gene in Holstein Friesian and beef cattle

\begin{tabular}{lcc}
\hline Source & Allele & $\mathrm{F}_{\text {ISki }}$ \\
\hline Holstein Friesian & & \\
Lembang AIC & A & -0.307 \\
Singosari AIC & B & -0.313 \\
Cipelang LEC & A & 0.046 \\
Sub total & B & 0.040 \\
& A & -0.003 \\
Beef Cattle & B & -0.003 \\
Simmental/Cipelang LEC & A & -0.045 \\
Limousin/Cipelang LEC & B & -0.050 \\
Brahman/Cipelang LEC & A & \\
Angus/Cipelang LEC & B & -0.189 \\
Sub total & A & -0.189 \\
& B & -0.346 \\
& A & 0 \\
\hline
\end{tabular}

Note: LAIC= Lembang Artificial Insemination Center; SAIC= Singosari Artificial Insemination Center; CLEC $=$ Cipelang Livestock Embryo Center.

\section{CONCLUSION}

GHRHIHaeIII gene in dairy and beef cattle is polymorphic, except in Brahman beef cattle. HF cattle has 
higher frequency in B allele. HF and beef cattle are in Hardy-Weinberg equilibrium, with low level diversity of the GHRHIHaeIII gene in HF cattle. This result will improve the understanding of the polymorphism of GHRH gene in dairy and beef cattle.

\section{ACKNOWLEDGMENT}

The authors acknowledge the head of Lembang Artificial Insemination Center, Singosari Artificial Insemination Center, and Cipelang Livestock Embryo Center for providing blood samples.

\section{REFERENCES}

Achtung, T. L., D. S. Buchanan, C. A. Lents, S. M. Barao, \& G. E. Dahl. 2001. Growth hormone response to growth hormone-releasing hormone in beef cows divergently selected for milk production. J. Anim. Sci. 79: 1295-1300.

Allendorf, F. W. \& G. Luikart. 2007. Conservation and The Genetic of Population. Blackwell Publishing, Australia.

Anderson, L. L., S. Jeftinija, \& C. G. Scanes. 2004. Growth Hormone secretion: molecular and cellular mechanism and in vivo approaches. Exp. Biol. Med. 229: 291-302.

Bizine, R., I. Miceikiene, L. Baltrenaite, \& N. Krasnopiorova. 2011. Association between growth hormone gene polymorphism and economic traits in pigs. Vet. Med. Zoot. 56: 27-31.

Cheong, H. S., D. H. Yoon, L. H. Kim, B. L. Park, Y. H. Choi, E. R. Chung, Y. M Cho, E. W. Park, I. C. Cheong, S. J. Oh, S. G. Yi, T. Park, \& H. D. Shin. 2006. Growth hormone-releasing hormone $(\mathrm{GHRH})$ polymorphisms associated with carcass traits of meat in Korean cattle. J. BioMed. Cent. 7: 1471-2156.

Cho, E. S., D. H. Park, B. Kim, W. Y. Jung, E. J. Kwon, \& C. W. Kim. 2009. Association of GHRH, H-FABP and MYOG polymorphisms with economic traits in pig. J. Anim. Sci. 22: $307-312$

DGLAH (Directorat General Livestock and Animal Health). 2011. Livestock and Animal Health Statistic. Ministry of Agriculture, Republic of Indonesia, Jakarta.

Dybus, A. \& W. Grzesiak. 2006. GHRH/HaeIII gene polymorphism and its associations with milk production traits in Polish Black-and-White cattle. Arch. Tierz. Dummerstorf 49: 434-438.

Frajman, P., V. Margeta, \& G. Kralik. 2008. Candidate genes for slaughter traits in pigs. Krmiva. Zagreb. 5: 267-273.

Franco, M. M., R. C. Antunes, H. D. Silva, \& L. R. Goulart. 2005. Association of PIT1, GH, and GHRH polymorphism with performance and carcass traits in Landrance pigs. J. Appl. Genet. 46: 195-200.

Hartman, M. L. 2000. Physiological Regulations of Growth Hormone Secretion. 2nd ed. Cambridge University Press, UK.

Jakaria, D. Duryadi, R. R. Noor, B. Tappa, \& H. Martojo. 2007. Evaluasi keragaman genetik hormone pertumbuhan (GH) pada sapi pesisir Sumatera Barat menggunakan penciri. Med. Pet. 30: 1-10.

Javanmard, A., N. Asadazadeh., M. H. Banabazi., \& J. Tavakolian. 2005. The allele and genotype frequencies of bovine pituitary specific transcription factor and leptin genes in Iranian cattle and buffalo populations using PCR-RFLP. Irianian J. of Biotechnol. 3: 104-108.

Kim, E., A. Goren, \& G. Ast. 2007. Alternative splicing: current perspective. Wiley Periodicals, Inc., BioEssays 30: 38-47. http://dx.doi.org/10.1002/bies.20692

Kmiec, M., I. K. Luczak, H. Kulig, A. Terman, H. Wierzbicki, \& A. Lepczynski. 2007. Associations between GHRH/HaeIII restriction polymorphism and milk production traits in a herd of dairy cattle. J. Anim. Vet. Adv. 6: 1298-1303.

Misrianti, R., A. Anggraeni, E. Andreas, \& C. Sumantri. 2012. Growth hormone gene polymorphism and its association with partial cumulative milk yields of Holstein Friesian dairy cattle. Med. Pet. 35: 145-151. http://dx.doi. org/10.5398/medpet.2012.35.3.145

Moioli B., F. Napolitano, \& G. Catillo. 2004. Genetic diversity between Piedmontese, Maremmana, and Podolica cattle breeds. J. Hered. 95: 250-256. http://dx.doi.org/10.1093/ jhered/esh032

Moody, D. E., D. Pomp, \& W. Barendse. 1995. Restriction fragment lenght polymorphism in amplification products of the bovine growth hormone releasing hormone gene. J. Anim. Sci. 73: 3789.

Nei, M. \& S. Kumar. 2000. Molecular Evolution and Phylogenetics. Oxford University Press, New York.

Nei, M. 1987. Molecular Evolutionary Genetics. Columbia University Press, New York.

Noor, R. R. 2008. Genetika Ternak. Penebar Swadaya, Jakarta.

Piatkowska, E. C., M. Szewczuk, \& S. Zych. 2011. Association between genetic polymorphism of growth-hormone-releasing hormone and the yield, chemical composition and technological parameters of cow milk. Arch. Tierz. Dummerstorf 54: 323-325.

Pierzchala, M., T. Blicharski, \& J. Kuryl. 2003. Growth rate and carcass quality in pigs are related to genotype at loci POU1F1/RsaI (Pit1/Rsa1) and GHRH/AluI. J. Anim. Sci. 21: 159-166.

Rejduch, B. 2008. Genes associated with production and health in farm animals. J. Cent. Eur. Agric. 9: 829-836.

Sambrook, J., E. F. Fritsch, \& T. Maniatis. 1989. Molecular Cloning, A Laboratory Manual. $2^{\text {nd }}$ ed. Cold Spring Harbour Lab. Press, New York.

Shingu, H., K. Hodate, S. Kushibiki, Y. Ueda, E. Touno, M. Shinoda, \& S. Ohashi. 2004. Hormonal and lactational responses to growth hormone-releasing hormone treatment in lactating Japanese black cows. J. Dairy Sci. 87: 1648-1693. http://dx.doi.org/10.3168/jds.S0022-0302(04)73321-4

Shingu, H., K. Hodate, S. Kushibiki, E. Touno, A. Oshibe, Y. Ueda, M. Shinoda, \& S. Ohashi. 2008. Effects or growth hormone-releasing hormone treatment on milk production and plasma hormones and metabolites in lactating Japanese Black cows under negative energy balance. J. Anim. Sci. 87: 1247-1253. http://dx.doi.org/10.2527/jas.2008-1220

Sumantri, C., R. Diyono, A. Farajallah, A. Anggraeni, \& E. Andreas. 2010. Pemanfaatan famili gen hormon pertumbuhan (GH, GHR, GHRH dan PIT-1) untuk mendeteksi keragaman genetik kerbau di Kabupaten Pandeglang dan Lebak Provinsi Banten. JITV. 15:286-296.

Sumantri, C., M. Imron, Sugyono, E. Andreas, M. Restu, \& A. B. L. Ishak. 2011. Growth hormone gene family $(\mathrm{GH}$, GHR, GHRH, and Pit-1) polymorphisms and its association with superovulation response, ovulation rate and embryo quality in Embryo Transfer Station (BET) of Cipelang. JITV 16: 127-140.

Szatkowska, I., A. Dybus, W. Grzesiak, M. Jdrzejczak, \& M. Muszyska. 2009. Association between the growth hormone releasing hormone (GHRH) gene polymorphism and milk production traits of dairy cattle. J. of App. Anim. Res. 36: 1. http://dx.doi.org/10.1080/09712119.2009.9707044

Weir, B. S. 1996. Genetic Data Analysis II : Method for Discrete Population Genetic Data. 2nd ed. Sinauer Associates. Sunderland.

Zulkharnaim, Jakaria, \& R. R. Noor. 2010. Identifikasi keragaman genetik gen reseptor hormon pertumbuhan (GHR।Alu I) pada sapi bali. Med. Pet. 33: 81-87. http:// dx.doi.org/10.5398/medpet.2010.33.2.81 